\title{
Investigation of Groundwater Quality from Selected Wells in Paiko, Northcentral Nigeria
}

\author{
AWEDA Abdulwahid Kolawole ${ }^{1}$, AMADI Akobundu Nwanosike ${ }^{2}$, KYARI Reuben ${ }^{1}$, SAMUEL Abel ${ }^{1}$ \& \\ SAMSON Bitrus Awu ${ }^{3}$ \\ ${ }^{1}$ Department of Geology and Mining, IBB University Lapai, Nigeria \\ ${ }^{2}$ Department of Geology, Federal University of Technology Minna, Nigeria \\ ${ }^{3}$ Gyro Earth Solutions Limited, Abuja, Nigeria \\ Correspondence: AWEDA Abdulwahid Kolawole, Department of Geology and Mining, IBB University Lapai, \\ Nigeria. Tel: 234-80-6307-6837. E-mail: akabdulwahid@ibbu.edu.ng
}

Received: January 6, 2020

Accepted: January 26, 2020 Online Published: March 30, 2020

doi:10.5539/jgg.v12n1p1

URL: http://dx.doi.org/10.5539/jgg.v12n1p1

\begin{abstract}
Groundwater from hand dug wells and boreholes in Paiko, northcentral Nigeria were subjected to physico-chemical as well as microbiological analysis to determine their suitability for drinking purpose. The water from the hand dug wells are predominantly calcium magnesium chloride $(\mathrm{Ca}-\mathrm{Mg}-\mathrm{Cl})$ water while those from boreholes are calcium magnesium bicarbonate water $\left(\mathrm{Ca}-\mathrm{Mg}-\mathrm{HCO}_{3}\right)$ facies. The results showed elevated cations and anions concentration in the hand dug wells in addition to the water being slightly acidic. Also, the nitrate concentration in the hand dug wells is above the maximum permissible limit of $50 \mathrm{mg} / 1$ postulated by World Health Organization (WHO) and Nigerian Standard for Drinking Water Quality (NSDQ). Microbiological analysis revealed Total Coliform Count of 100cfu and 360cfu in the hand dug wells and borehole respectively signifying faecal contamination. The study revealed that improper sewage systems as well as poor waste disposal is responsible for the poor water quality as well as elevated concentration of nitrate in hand dug wells, and as such the shallow aquifer groundwater in the area are not safe for drinking purpose with respect to all the parameters taken together.
\end{abstract}

Keywords: Groundwater, Aquifer, Water Quality, Contamination, Borehole

\section{Introduction}

Groundwater has been considered an important environmental and human resource for decades. It is generally of desirable quality because in most cases, it is either filtered through permeable layers or it is protected by impermeable layers overlying it (De Giglio et al., 2015). A high percentage of human population both in the rural and urban areas depend on it for their daily domestic use and consumption as well as agricultural and industrial use. However, groundwater has come under a lot of pressure in recent times thereby depleting its quality. Groundwater quality analysis is a very important aspect of groundwater studies. This reveals the water quality viz-a-viz its suitability for domestic and industrial purposes. Groundwater quality is determined by both natural and anthropogenic factors (Johnson et al., 2011). The natural chemical composition of groundwater is influenced by some physical characteristics of the well and the adjoining land. Some of the characteristics are the soil condition at the surface, land use as well as the geology of the bed rock (lithology, mineralogy, chemical composition and structure) aquifers from where the water is drawn (Johnson et al., 2011). The bulk of groundwater contamination cases are as a result of anthropogenic factors prominent among which are due to use of pesticides and fertilizers and industrial waste which are subsequently leached into the groundwater.

The suitability of groundwater for various uses is determined by various parameters. These include odor, color, taste, acidity, alkalinity, hardness and total dissolved solids (Ali et al., 2015). These parameters should have certain normal value. If these deviate from their normal values, the quality of water changes. These parameters have standards above which the water is considered unsafe for domestic or industrial use. Also, inorganic constituents of groundwater are important in determining its suitability for drinking purpose. They occur in various concentrations due to chemical and biochemical interactions between water and the host geological materials. In determining the suitability of groundwater for drinking and domestic purpose, inorganic 
contaminants such as salinity, chloride, fluoride, nitrate, iron and arsenic are very important. The study evaluates the groundwater quality of boreholes and shallow wells around Paiko, northcentral Nigeria in order to assess its suitability for drinking purpose.

\section{The Study Area}

Paiko is located along the Minna - Suleja highway in northcentral Nigeria and is bounded by latitude $09^{0} 45^{\prime} \mathrm{N}-$ $09^{0} 49^{\prime} \mathrm{N}$ and longitudes $06^{0} 23^{\prime} \mathrm{E}-06^{0} 24^{\prime} \mathrm{E}$. It is a densely populated region which is witnessing very rapid development as a result of its proximity to major cities such as Minna, Suleja and the nation's capital, Abuja. The mean annual rainfall is between $1200 \mathrm{~mm}-1300 \mathrm{~mm}$ spanning from April to October with maximum rain recorded in August. The area is drained by many small streams which discharge into river Muidna. Geologically, the area falls within the Minna granitic suite which is made up of metasedimentary and granitic rocks (Figure 1). The metasediments include quartzites and gneisses while the metavolcanics are mainly granites. The rocks in the study area are mainly light colored medium to coarse grained biotite granites. The biotites are threadlike with some disoriented in the ground mass (Alhassan et al., 2015). The feldspars occur as fine to medium grained. The grains are however cloudy as a result of alteration mainly along the twin planes while the quartz minerals in the rock show strong fracturing (Ajibade, 1980).

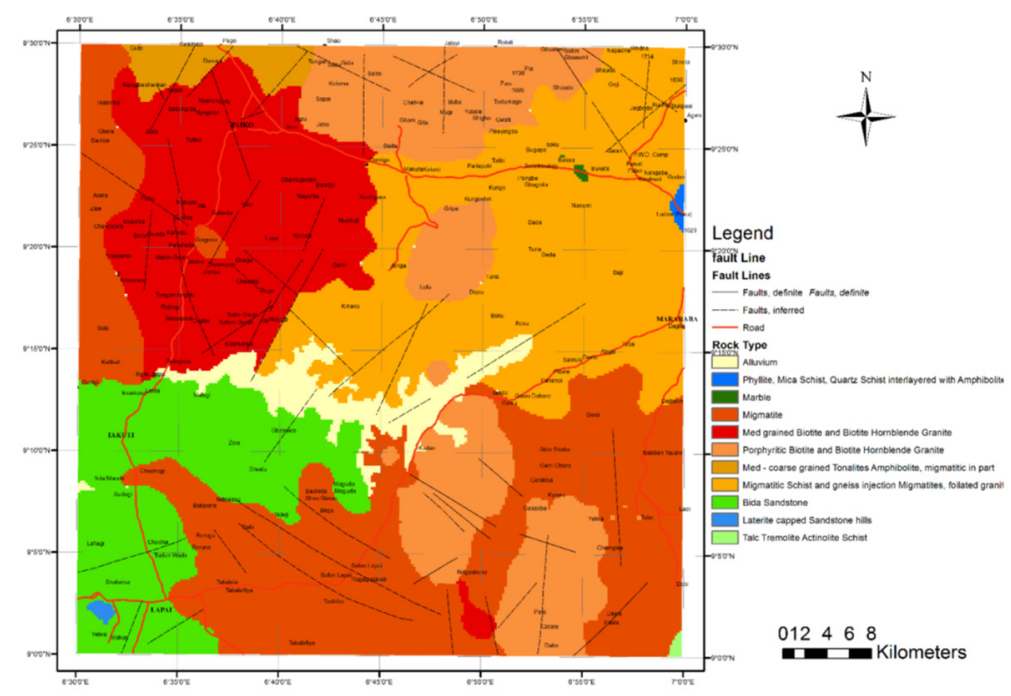

Figure 1. Geological Map of Paiko Sheet (Source: Alhassan et al., 2015)

\section{Methods of Study}

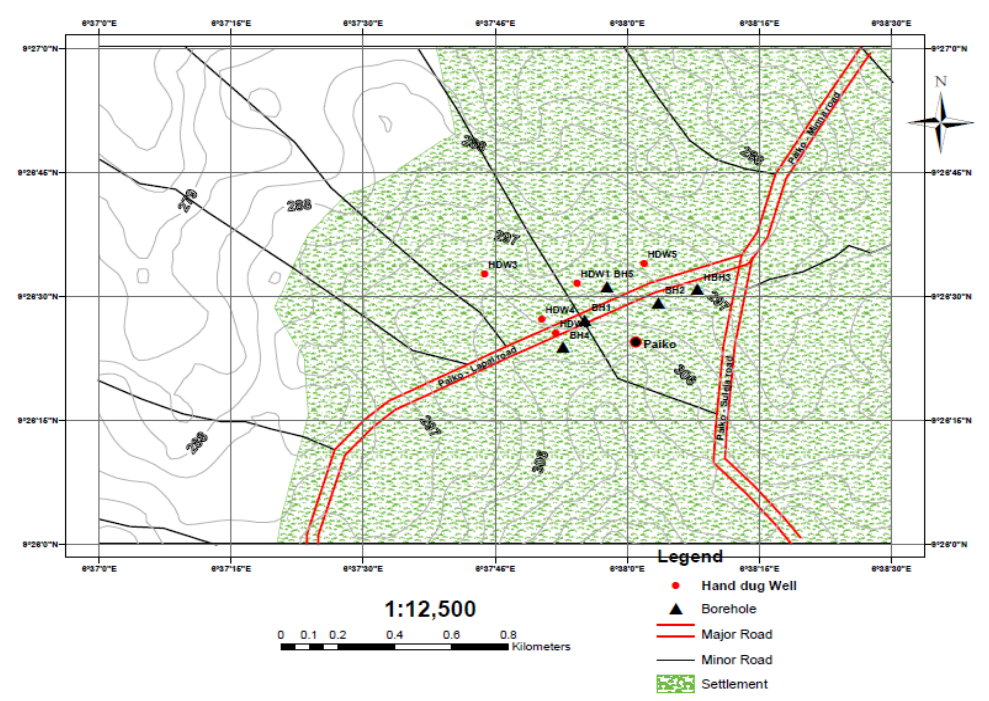

Figure 2. Sample Locations within the Study Area 
Ten groundwater samples (5 each from shallow hand dug wells and boreholes) were collected randomly within the study area (Figure 2), in April 2018, from commercial boreholes and wells that serve larger human populations. Samples were collected within a $1 \mathrm{~km}^{2}$ region within the study area. The samples were collected into half gallon containers for the determination of physico-chemical parameters. Additional half gallon water samples were collected for microbial analysis. Air bubbles were minimized by filling up the container before closing during sampling. All materials involved in the sampling were kept clean to avoid contaminating the water.

The collected samples were preserved at low temperature as against preservation with chemicals and away from sunlight to prevent bacterial and algae growth and were immediately transported to the federal ministry of water resources water quality reference laboratory, Minna for analysis. This was preferred in order to maintain the sample integrity. Flame photometric, titrimetric and colorimetric methods were used for the cations $\left(\mathrm{Na}^{+}, \mathrm{Mg}^{2+}\right.$, $\left.\mathrm{Ca}^{2+}, \mathrm{K}^{+}, \mathrm{Fe}^{2+}\right)$ analysis while titrimetric and colorimetric methods were used for the anions $\left(\mathrm{CO}_{3}^{-}, \mathrm{HCO}_{3}^{-}, \mathrm{SO}_{4}{ }^{2-}\right.$, $\mathrm{Cl}^{-}, \mathrm{NO}_{3}{ }^{-}, \mathrm{PO}_{4}{ }^{2-}$ ) analysis. The collected water was also analyzed for various fecal-indicator bacteria (including total coliform, E. coli, fecal streptococcus, and fecal coliform). Membrane filtration technique was used for the microbial analysis. The quality of the laboratory chemical analysis was checked using the ionic balance error. The error was less than $5 \%$.

\section{Results and Discussion}

\subsection{Physical Properties of Water}

The results of the physico-chemical properties of the water are presented in Table 1. Water from the hand dug wells are considered colored with true color unit (TCU) values of between 8 and 65. Of the samples collected from boreholes, only BH 1 water has value higher than the maximum permissible limit of 15TCU (NSDQ, 2007) while HDW 3 and HDW5 are the hand dug well samples with values below this permissible limit. Water color above $15 \mathrm{TCU}$ is easily detectable in a glass cup while color below this is not physically noticed. Although no health effect has been reported as a result of color, the aesthetic and acceptability to consumers can be greatly affected. The mean turbidity for the borehole samples is 10.06NTU with BH 1 having the highest turbidity value of 35.2NTUwhile the mean value for the hand dug well is $4.2 \mathrm{NTU}$ with highest value obtained in HDW 4. BH 1, 2 and 4 as well as HDW 1 and 4 have turbidity values higher than the WHO (2017) maximum permissible limit of 4NTU indicating the presence of suspended particles in the water which will reduce the acceptability of the water for drinking purpose. The mean total dissolved solids (TDS) are $365.6 \mathrm{mg} / 1$ and $773.4 \mathrm{mg} / 1$ for water from boreholes and hand dug wells respectively. Water is generally portable at TDS less than $600 \mathrm{mg} / 1$ (WHO, 2017). This palatability is almost totally lost at TDS levels greater than $1000 \mathrm{mg} / \mathrm{l}$. All the hand dug well samples have TDS values significantly above the maximum permissible limit except for HDW 3 which is lower.

Table 1. Results of Physico-Chemical Parameters Conducted

\begin{tabular}{|c|c|c|c|c|c|c|c|c|c|c|c|c|c|c|c|c|c|c|}
\hline $\mathbf{S} / \mathbf{N}$ & SAMPLE & pH & TA & TH & TDS & $\mathbf{E} / \mathbf{C}$ & Col & Turbidity & $\mathrm{Na}$ & $\mathbf{K}$ & $\mathrm{Ca}$ & $\mathbf{M g}$ & $\mathrm{SO}_{4}$ & $\mathrm{NO}_{3}$ & $\mathrm{Cl}$ & $\mathrm{PO}_{4}$ & $\mathbf{F e}$ & $\mathrm{HCO}_{3}$ \\
\hline 1 & BH1 & 6.98 & 70 & 210 & 348 & 520 & 65 & 35.2 & 14 & 5 & 51.3 & 20 & 10 & 34.1 & 12.1 & 4.32 & 0.81 & 70 \\
\hline 2 & $\mathrm{BH} 2$ & 7.25 & 73 & 218 & 359 & 537 & 12 & 4.1 & 16 & 5 & 53.7 & 20.5 & 11 & 29.7 & 12.6 & 4.78 & 0.07 & 73 \\
\hline 3 & BH3 & 7.34 & 90 & 254 & 408 & 610 & 10 & 3.8 & 27 & 7 & 68.9 & 20 & 24 & 47.3 & 18.3 & 7.21 & 0.09 & 90 \\
\hline 4 & BH4 & 7.01 & 35 & 80 & 189 & 283 & 13 & 4.7 & 7 & 3 & 16.8 & 9.27 & 4 & 10.8 & 5.99 & 1.09 & 0.03 & 35 \\
\hline 5 & BH5 & 7.43 & 96 & 262 & 424 & 639 & 8 & 2.5 & 31 & 8 & 75.4 & 18.1 & 26 & 53.4 & 20.1 & 7.81 & 0.1 & 96 \\
\hline 6 & HDW1 & 5.7 & 198 & 260 & 826 & 1233 & 30 & 7 & 89 & 30 & 64 & 24.4 & 61 & 78 & 120 & 7.11 & 0.45 & 198 \\
\hline 7 & HDW2 & 6.4 & 176 & 340 & 928 & 1386 & 23 & 1 & 95 & 35 & 80 & 48.8 & 52 & 83.5 & 130 & 8.19 & 0.32 & 176 \\
\hline 8 & HDW3 & 6.9 & 90 & 230 & 526 & 785 & 0 & 1 & 70 & 28 & 40 & 31.7 & 33 & 43.7 & 75.6 & 5.78 & 0.08 & 90 \\
\hline 9 & HDW4 & 5.2 & 165 & 228 & 769 & 1149 & 56 & 10 & 79 & 30 & 64 & 16.7 & 70 & 60.1 & 121 & 6.32 & 0.75 & 165 \\
\hline 10 & HDW5 & 6.6 & 156 & 232 & 818 & 1222 & 0 & 2 & 91 & 32 & 56 & 22.4 & 42 & 75.8 & 118 & 6.99 & 0.06 & 156 \\
\hline \multicolumn{2}{|c|}{ WHO (2017) } & $6.5-8.5$ & - & - & $\leq 600$ & $\leq 1000$ & - & $\leq 4$ & $\leq 200$ & - & - & - & $<250$ & $\leq 50$ & $200-300$ & - & $\leq 0.3$ & - \\
\hline \multicolumn{2}{|c|}{ NSDQ (2007) } & - & - & $\leq 150$ & $\leq 500$ & - & $\leq 15$ & $\leq 5$ & $\leq 200$ & - & - & $\leq 0.20$ & $\leq 100$ & $\leq 50$ & $\leq 250$ & - & $\leq 0.3$ & - \\
\hline
\end{tabular}

$\mathrm{TA}=$ Total Alkalinity (mg/l); TH = Total Hardness (mg/l); TDS = Total Dissolved Solids (mg/l); E/C = Electrical Conductivity $(\mu \mathrm{S} / \mathrm{cm}) ; \mathrm{Col}=$ Color $(\mathrm{TCU})$ 
The range of $\mathrm{pH}$ in the boreholes studied is 6.98 to 7.43 and 5.20 to 6.90 for hand dug wells. Optimum $\mathrm{pH}$ is usually in the range of $6.8-8.5$ (WHO, 2017). Values below this indicate corrosiveness. All the borehole and HDW3 samples are considered non corrosive while the other hand dug well samples are considered corrosive and will corrode pipes and storage systems.

\subsection{Chemical Properties}

The water is generally regarded to be hard according to the NSDQ standard with average total hardness of $231 \mathrm{mg} / \mathrm{l}$. Water hardness is primarily as a result of the presence of calcium and magnesium cations as well as anions such as bicarbonate, carbonate, chloride and sulfate in water. The degree of hardness of drinking water is important for aesthetic acceptability by users as well as for economic and operational considerations (WHO, 2017). Water hardness has no known adverse effects but is unsuitable for domestic use (Sadashivaiah et al., 2008).

Chemical data of representative samples from the study area presented by plotting them on a Piper-tri-linear diagram. The borehole water is classified as Calcium Magnesium Bicarbonate water when plotted on the Piper's diagram (Figure 3) while the water from hand-dug are classified as mixed calcium magnesium chloride water except HDW 5 water which is a sodium chloride water.

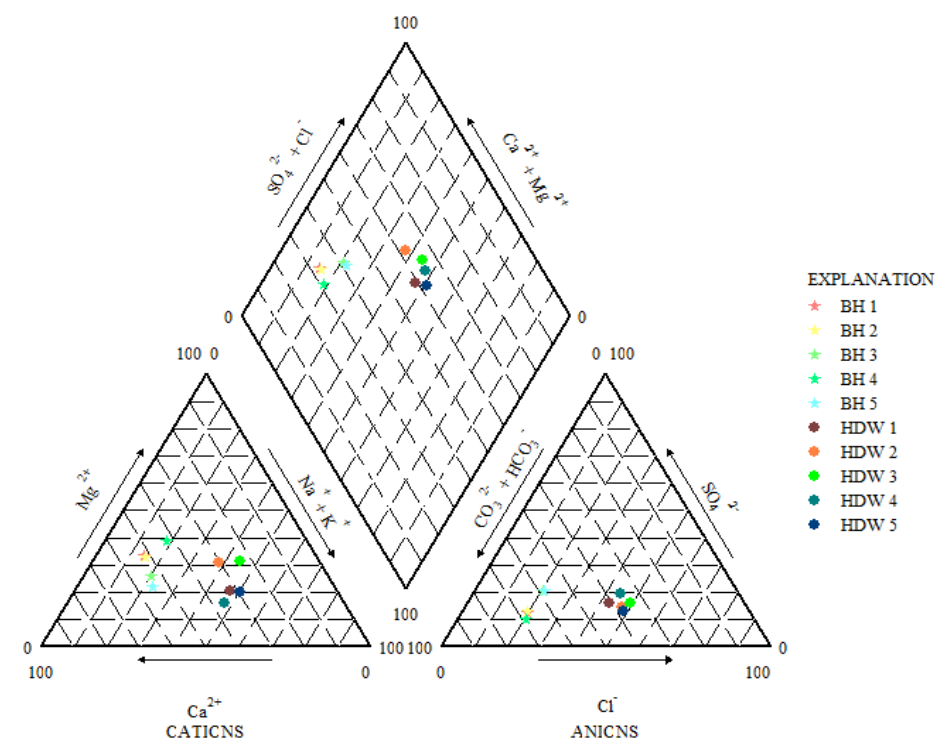

Figure 3. Plot of Anions and Cations on the Piper's Diagram

The WHO and NSDQ permissible nitrate limit for drinking water is $50 \mathrm{mg} / \mathrm{l}$. Samples from hand dug well have elevated concentration of nitrate beyond the permissible limit except HDW 3 sample. All the borehole samples have nitrate concentration below the limit except BH 5 with slightly elevated concentration. Nitrate can reach both surface and groundwater as a result of agricultural activity, from wastewater disposal, leachate from dumpsites and from oxidation of nitrogenous waste products in human and animal faeces including septic tanks (WHO, 2017) and as such, high nitrate content is an indication of urban pollution (Amadi et al., 2015). High concentration of nitrate is known to cause cyanosis as well as asphyxia (blue - baby syndrome) in infants under 3 months (NSDQ, 2007) as well as methaemoglobinaemia and thyroid effects. All the samples have magnesium value higher than the WHO and NSDQ permissible limit of $0.20 \mathrm{mg} / \mathrm{l}$. Although this has no health implication, it can greatly affect consumer acceptability of the water. All other chemical parameters of the water are within the acceptable limits.

Generally, the physico -chemical study of groundwater quality in the area reveals that shallow wells have a higher concentration of cations and anions (Figure 4) and are polluted. This is attributable to poor waste disposal and improper sewage systems. Although the boreholes are relatively of a higher quality, there are indications of downward infiltration from the shallow aquifer which has slightly impacted on the quality of the water. 


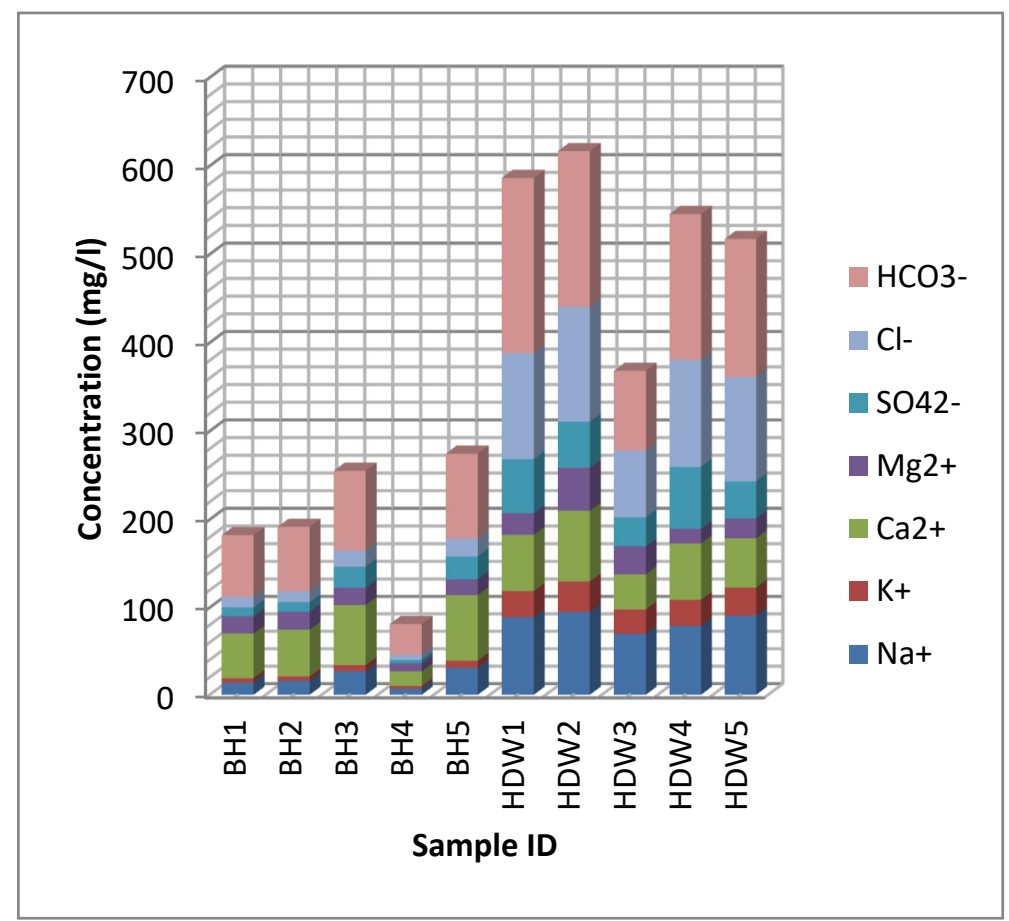

Figure 4. Stacked Bar Chart of Major ion Concentration

\subsection{Microbial Properties}

The result of the microbial analysis is presented in Table 2. Total coliforms are a group of bacterial commonly found in soils or plants as well as the intestines of mammals which include humans. They are not likely to cause illness but their presence is an indication of vulnerability of the water source to contamination by harmful microorganisms. The presence of fecal coliform in well water is commonly an indication of recent contamination of groundwater by human sewage or animal droppings which could contain viruses, bacteria or disease causing organism. The maximum permissible total coliform level in drinking water is $10 \mathrm{cfu}$ while the presence of any count of fecal coliform or fecal streptococci in water is potentially harmful. Of the borehole samples studied, only BH1 have total coliforms (15 cfu) above the maximum permissible level. Fecal coliforms and fecal streptococci were not detected in the borehole water. Water from hand dug wells are heavily contaminated with very high counts of total coliforms, fecal coliforms and fecal streptococci which are above the permissible limits. Boreholes are free from these pathogens because of natural aquifer attenuation as they are filtered by mechanisms such as adsorption, absorption and ionic exchange.

Water containing total and fecal coliforms above the permissible level should generally not be consumed in any form without disinfection. This water can cause illnesses which include diarrhea and nausea which could be severe and lead to death in babies, children, elderly as well as people with immune deficiencies or illnesses.

Table 2. Microbial Analysis Result

\begin{tabular}{lllll}
\hline S/N & SAMPLE & Total Coliform (cfu/100ml) & Faecal Coliform (cfu/100ml) & Faecal Streptococci (cfu/100ml) \\
\hline $\mathbf{1}$ & BH1 & 15 & 0 & 0 \\
$\mathbf{2}$ & BH2 & 3 & 0 & 0 \\
$\mathbf{3}$ & BH3 & 5 & 0 & 0 \\
$\mathbf{4}$ & BH4 & 0 & 0 & 0 \\
$\mathbf{5}$ & BH5 & 7 & 0 & 0 \\
$\mathbf{6}$ & HDW1 & 360 & 100 & 120 \\
$\mathbf{7}$ & HDW2 & 100 & 48 & 44 \\
$\mathbf{8}$ & HDW3 & 188 & 80 & 96 \\
$\mathbf{9}$ & HDW4 & 200 & 60 & 100 \\
$\mathbf{1 0}$ & HDW5 & 280 & 72 & 80 \\
\hline
\end{tabular}




\section{Conclusions}

The quality of groundwater in shallow and deep water wells in Paiko, northcentral Nigeria was investigated. Groundwater from hand dug wells are generally colored, slightly acidic and classified as mixed calcium magnesium chloride water as against groundwater from boreholes which are less coloured, alkaline and are classified as calcium magnesium bicarbonate water. The shallow water table in the overburden aquifer from where hand dug wells source their water makes them vulnerable to contamination. Improper sewage systems aided by poor waste disposal is believed to be the cause of the water quality issues highlighted as well as the high nitrate concentration in the hand dug wells studed. Water samples collected form boreholes are generally of good quality because they tap water form very deep aquifers and are properly constructed. Bacteriological analysis of the water samples revealed total coliform of between $100 \mathrm{cfu}$ and $360 \mathrm{cfu}$, fecal coliform of $48 \mathrm{cfu}$ and $100 \mathrm{cfu}$ and fecal streptococci of $44 \mathrm{cfu}$ and $120 \mathrm{cfu}$ in all the hand dug wells studied. No fecal coliform and fecal streptococci were detected in the borehole water while total coliforms are below the maximum permissible level except in BH 1.

The study has established that hand dug wells in Paiko are poor bacteriologically. It can be attributed to the poor hygiene, sanitation, leachate from unlined or poorly lined sewage systems and pit latrine as well as open defecation in the area. The high concentrations of coliforms are responsible for the elevated values of TDS, EC and nitrate in the area. Generally, the shallow hand dug wells are polluted and unsafe for consumption without treatment. Hence, detailed study of the groundwater quality and contaminant migration is important to undercover the extent of the pollution and design remediation plans. However, the borehole water is safe and fit for human consumption according to the WHO and NSDQ standard. It is recommended that groundwater in the area should be abstracted using well developed boreholes rather than hand dug shallow wells. They should also be located far away from sewage systems and waste dump sites to further reduce the risk of contamination. In the event where hand dug wells are the only available option, water obtained from them should be heated to boiling point so that it is bacterial free before consumption. The wells should also be located at least 30 meters away from sewage systems and waste dump sites to protect them against contaminant infiltration and should be treated regularly.

\section{Conflict of interests}

The authors declare that there is no conflict of interests regarding the publication of this paper.

\section{Reference}

Ajibade, A. C. (1980). Geotectonic evolution of the Zungeru Region, Nigeria. Unpublished Ph.D. Thesis, University of Wales, Aberyswyth.

Alhassan, D. U., Ugbor, D. O., Ejepu, S. J., Mufutau, O. J., \& Mohammed, A. (2015). Seismic Refraction Survey for Groundwater Potentials of Northern Paiko Area. Niger State, Nigeria. IOSR Journal of Applied Geology and Geophysics, 3(2), 41-48.

Ali, J., Kumar, M., Saraf, S., \& Jain, T. (2015). Study of water quality of shallow groundwater. Advances in Applied Science Research, 6(10), 78-87.

Amadi, A. N., Okunlola, I. A., Dan-Hassan, M. A., Aminu, T., \& Ola. (2015). Evaluation of Groundwater Quality in Shallow Aquifers in Minna, North-Central Nigeria using Pollution Load Index. Journal of Natural Sciences Research, 5(8), 45-56.

De Giglio, O., Quaranta, A., Barbuti, G., Napoli, C., Caggiano, G., \& Montagna, M. T. (2015). Factors influencing groundwater quality: Towards an integrated management approach. Ann Ig, 27, 52-57.

Ejepu, S. J., Olasehinde, P. I., Omar, D. M., Abdullahi, D. S., Adebowale, T. A., \& Ochimana, A. (2015). Integration of Geology, Remote Sensing and Geographic Information System in assessing groundwater potential of Paiko Sheet 185 North-Central Nigeria. J. Inf. Educ. Sci. Technol., 2, 145-155.

Idris-Nda, A., Abubakar, S. I., Waziri, S. H., Dadi, M. I., \& Jimada, A. M. (2015). Groundwater development in a mixed geological terrain: A case study of Niger State, central Nigeria. Water Resources Management, 8, 77-87.

Johnson, G. C., Zimmerman, T. M., Lindsey, B. D., \& Gross, E. L. (2011). Factors affecting groundwater quality in the Valley and Ridge aquifers, eastern United States, 1993-2002: U.S. Geological Survey Scientific Investigations Report, 5115, 70.

NSDQ. (2007). Nigerian Standard for Drinking Water Quality. Nigerian Industrial Standard (NIS), 554, 30. 
Sadashivaiah, C., Ramakrishnaiah, C. R., \& Ranganna, G. (2008). Hydrochemical Analysis and Evaluation of Groundwater Quality in Tumkur Taluk, Karnataka State, India. Int. J. Environ. Res. Public Health, 5(3), 158-164.

World Health Organization. (2017). Guidelines for drinking water quality (p. 541). Fourth edition incorporating the first addendum, Geneva.

\section{Copyrights}

Copyright for this article is retained by the author(s), with first publication rights granted to the journal.

This is an open-access article distributed under the terms and conditions of the Creative Commons Attribution license (http://creativecommons.org/licenses/by/4.0/). 